\title{
Amino Acid Modulation of Renal Phosphatidylcholine Biosynthesis in the Rat
}

\author{
Leah J. Havener and F. Gary Toback, Department of Medicine, The University of \\ Chicago, Pritzker School of Medicine, Chicago, Illinois 60637
}

\begin{abstract}
A B S T RACT The hypothesis that amino acids act as modifiers of phospholipid biosynthesis was tested in renal cortical cells from normal rats. The rate of $\left[{ }^{14} \mathrm{C}\right]$ choline incorporation into phospholipid in cortical slices was enhanced by the addition of lysine or arginine to the incubation medium, and reduced by phenylalanine, aspartic acid, or four other amino acids. Lysine and aspartic acid appeared to modify the cholinephosphotransferase reaction in which cytidine 5 '-diphosphocholine (CDP-choline) and 1,2-diacylglycerol react to form phosphatidylcholine, the major phospholipid of renal membranes. Since this enzymatic reaction takes place in the endoplasmic reticulum, the effect of single amino acids on microsomal preparations was examined. Iysine increased CDP-choline: 1,2-diacylglycerol cholinephosphotransferase activity by $95 \%$, whereas aspartic acid reduced activity by $65 \%$, in a concentration-dependent manner. For both substrates in the reaction, amino acids modulated enzyme activity by altering the maximum velocity without changing the apparent $K_{\mathrm{m}}$. These observations in intact renal cells and in microsomal preparations indicate that changes in cellular amino acid concentrations could modify the biosynthetic rate of phosphatidylcholine, and suggest a mechanism that could coordinate the biosynthesis of phospholipid and protein.
\end{abstract}

\section{INTRODUCTION}

The mechanisms by which phospholipid and protein biosynthesis are coordinated for new membrane formation during cell growth are unknown. We have previously studied phospholipid biosynthesis in regenerating kidney cells after mercuric chloride-induced tubular necrosis (1-3). Phospholipid biosynthesis via the Kennedy pathway was assessed using choline as a precursor of phosphatidylcholine, the major cholinecontaining phospholipid in renal membranes (4-8). In

A portion of this work has been published in abstract form. 1979. Clin. Res. 27: 432A.

Received for mublication 21 May 1979 and in revised form 8 October 1979. this pathway, choline is phosphorylated to form phosphorylcholine, which reacts with cytidine triphosphate to form cytidine $5^{\prime}$-diphosphocholine (CDP-choline), ${ }^{1}$ the immediate precursor of phosphatidylcholine. The rate of $\left[{ }^{14} \mathrm{C}\right]$ choline incorporation into phosphatidylcholine in regenerating renal tissue was enhanced by the provision of a mixture of 15 amino acids in vitro and in vivo without a detectable increase in phospholipid breakdown. Amino acid enhancement of phosphatidylcholine synthesis was also observed in renal tissue from normal animals. Protein synthesis is also stimulated by an increased amino acid supply in regenerating kidney (9) and in normal liver and cardiac muscle (10-13). These observations prompted us to test the hypothesis that specific amino acids can act as modulators of phospholipid biosynthesis via the Kennedy pathway, and could thereby coordinate the synthesis of phosphatidylcholine and protein for membrane formation.

\section{METHODS}

Male Sprague-Dawley rats (Sprague-Dawley Farms, Madison, Wis.) weighing $175-250 \mathrm{~g}$ were killed by decapitation and their kidneys removed and decapsulated. Renal inner cortical slices were cut and preincubated in $2 \mathrm{ml}$ of Krebs-Ringer bicarbonate medium for $10 \mathrm{~min}$ at $38^{\circ} \mathrm{C}$ in a shaking incubator as described $(14,15)$. Slices were then transferred to flasks containing $2 \mathrm{ml}$ of $20 \mu \mathrm{M}$ [methyl $-{ }^{14} \mathrm{C}$ ]choline chloride (30 $\mathrm{mCi} / \mathrm{mmol} \mathrm{sp}$ ) act) in Krebs-Ringer bicarbonate medium and one of the following amino acids: $20 \mathrm{mM}$ L-lysine, $20 \mathrm{mM}$ L-arginine, $1 \mathrm{m.M}$ L-glutamic acid, $3 \mathrm{m.M}$ L-histidine, $3 \mathrm{m.M}$ L-methionine, $20 \mathrm{~m} . \mathrm{ll}$ L-leucine, $20 \mathrm{m.M}$ L-phenylalanine, or $5 \mathrm{m.M}$ L-aspartic acid. The amino acid concentration was set so that the $\mathrm{pH}$ of the incubation medium was maintained between 7.3 and 7.6. As a control for the amino acid under study slices were incubated in isohydric equimolar glucose solutions, because glucose concentrations up to $20 \mathrm{~m}$.M did not change the rate of $\left[{ }^{14} \mathrm{C}\right]$ choline incorporation into phospholipid. Flasks were gassed for $30 \mathrm{~s}$ with $95 \% \mathrm{O}_{2}$ and $5 \% \mathrm{CO}_{2}$ and the slices were then incubated for $10 \mathrm{~min}$. After incubation radioactivity in the trichloroacetic acid-soluble and -insoluble frac-

\footnotetext{
${ }^{1}$ Abbreviations used in this paper: CDP-choline, cytidine 5 '-diphosphocholine; ICF, intracellular fluid; $\mathrm{V}_{\max }$, maximum velocity.
} 


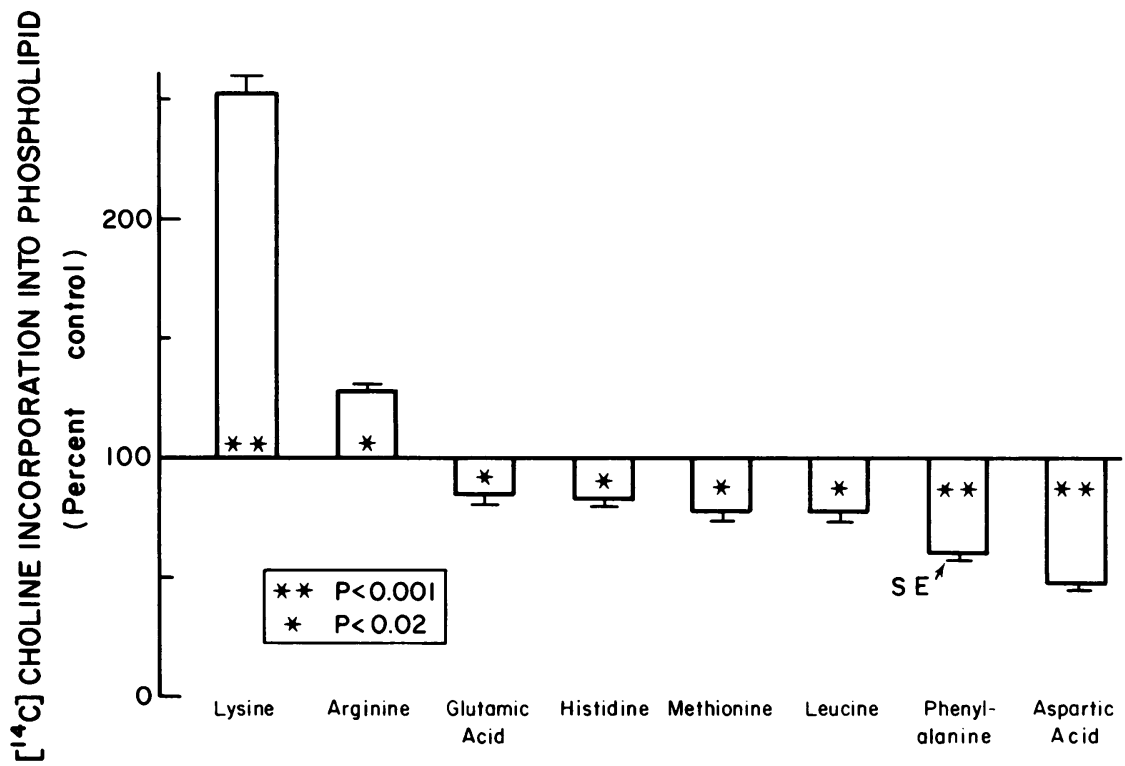

FIGURE 1 Effect of specific amino acids on $\left[{ }^{14} \mathrm{C}\right]$ choline incorporation into phospholipid in renal cortical slices. Choline incorporation was expressed as a percentage of the rate observed at equimolar glucose concentrations $(3.80 \pm 0.09 \mathrm{pmol} / 10 \mathrm{~min}$ per $\mathrm{mg}$ wet tissue wt). Values are means $\pm \mathrm{SE}$ of at least eight determinations from no fewer than four rats.

tions was determined as described (14). More than $99.8 \%$ of the radioactivity in the acid-insoluble fraction was in lipid because it was extracted with chloroform: methanol (2:1, vol: vol) (1-3). Thin-layer chromatography of the lipid extracts indicated that $99 \%$ of the radioactivity was in phosphatidylcholine and the remainder in lysophosphatidylcholine and sphingomyelin $(16,17)$.

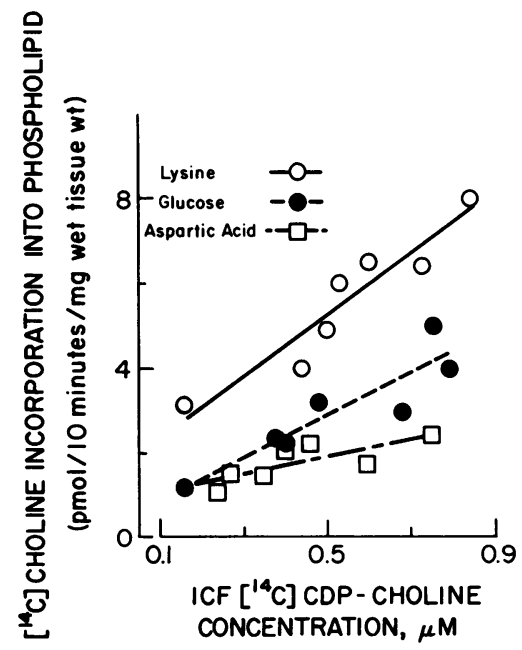

FIGURE 2 Incorporation of $\left[{ }^{14} \mathrm{C}\right]$ choline into phospholipid in renal cortical slices as a function of the intracellular $\left[{ }^{14} \mathrm{C}\right] \mathrm{CDP}$ choline concentration in the presence of lysine, glucose or aspartic acid. The concentration of $\left[{ }^{14} \mathrm{C}\right] \mathrm{CDP}$-choline reached in the ICF was estimated from the known choline specific activity and expressed as the number of micromoles formed per liter ICF. Each value is the mean of independent determinations on tissue from two different rats.
To define the locus of amino acid action on the reactions of the Kennedy pathway slices were preincubated as above and then incubated for $10 \mathrm{~min}$ in the presence of either $20 \mathrm{mM}$ L-lysine, $20 \mathrm{mM}$ glucose, or $5 \mathrm{mM} \mathrm{L}$-aspartic acid at medium $\left[{ }^{14} \mathrm{C}\right]$ choline concentrations between 5 and $40 \mu \mathrm{M} .\left[{ }^{14} \mathrm{C}\right]$ choline metabolites in perchloric acid extracts of the slices and in $50 \%$ ethanol extracts of the medium were measured by paper chromatography $(1,8)$. Values for each $\left[{ }^{14} \mathrm{C}\right]$ metabolite formed were expressed as picomoles per $10 \mathrm{~min}$ per milligram wet tissue weight. $\left[{ }^{14} \mathrm{C}\right]$ choline uptake into the intracellular fluid (ICF) was calculated as the difference between total tissue $\left[{ }^{14} \mathrm{C}\right]$ choline and final $\left[{ }^{14} \mathrm{C}\right]$ choline in the extracellular fluid space of the slice. The ICF space was calculated as the difference between tissue water and extracellular fluid space estimated from the distribution of $\left[{ }^{14} \mathrm{C}\right]$ inulin (18). The concentration of $\left[{ }^{14} \mathrm{C}\right]$ choline, $\left[{ }^{14} \mathrm{C}\right]$ phosphorylcholine, and $\left[{ }^{14} \mathrm{C}\right]-$ CDP-choline reached in the ICF was estimated from the known choline specific activity.

The capacity of amino acids to modulate CDP-choline:1,2diacylglycerol cholinephosphotransferase activity (EC 2.7.8.2) was measured in microsomal preparations $(19,20)$. Homogenates of inner cortical tissue were prepared in $0.25 \mathrm{M}$ sucrose, 10 $\mathrm{mM}$ Tris- $\mathrm{HCl}$ ( $\mathrm{pH} 8.5$ ), and $1 \mathrm{mM}$ EGTA. After sedimenting the nuclei and mitochondria by centrifugation at $9,000 \mathrm{~g}$ for $10 \mathrm{~min}$, microsomes were collected from the supernate by centrifugation at $100,000 \mathrm{~g}$ for $60 \mathrm{~min}$. The microsomal pellet was resuspended in the above solution at a protein concentration of $8-10 \mathrm{mg} / \mathrm{ml}$ and was used as an enzyme source. The standard reaction mixture $(0.2 \mathrm{ml})$ contained $25 \mathrm{mM} \mathrm{MgCl}$, $50 \mathrm{mM} \mathrm{KCl}, 0.1 \mathrm{M}$ imidazole (pH 8.5), $25 \mathrm{mM}$ DL-dithiothreitol, $2.5 \mathrm{mM}\left[\right.$ methyl $\left.-{ }^{14} \mathrm{C}\right] \mathrm{CDP}$-choline $(0.1 \mathrm{mCi} / \mathrm{mmol}), 7 \mathrm{mM} \mathrm{1,2-}$ diacylglycerol from egg lecithin (Sedary Research Laboratories, London, Ontario) dispersed in $0.01 \%$ Tween 20 by sonication, and about $1 \mathrm{mg}$ of enzyme protein. Enzyme activity at various $\left[{ }^{14} \mathrm{C}\right] \mathrm{CDP}$-choline $(0.1-3.75 \mathrm{mM})$ and 1,2-diacylglycerol (1-7 $\mathrm{mM}$ ) concentrations was assessed in the presence of each of the following compounds: L-lysine, L-aspartic acid, L-tryptophan or glucose at $20 \mathrm{mM}$. The $\mathrm{pH}$ of the reaction mixture 
was unchanged by the addition of these compounds. The reaction was started by the addition of enzyme to the preincubated reactants: After a 4 -min incubation at $38^{\circ} \mathrm{C}$ the reaction was stopped by the addition of chloroform: methanol $(2: 1, \mathrm{vol}: \mathrm{vol})$ and radioactivity in the lipid extract determined as described (15). Values for boiled microsomal protein blanks were subtracted from the observed activities. Microsomal protein concentrations were determined according to Lowry et al. (21). Activity was expressed as nanomoles $\left[{ }^{14} \mathrm{C}\right] \mathrm{CDP}$-choline incorporated into lipid per min per milligram microsomal protein.

Data were compared by Student's $t$ test $(22) ; P$ values $<0.05$ were accepted as significant. Values for apparent $K_{\mathrm{m}}$ and maximum velocity $\left(V_{\max }\right)$ were determined by Eadie-Hofstee analysis $(23,24)$.

All chemicals were purchased from Sigma Chemical Co., St. Louis, Mo., and radioactive isotopes from New England Nuclear, Boston, Mass., unless otherwise stated.

\section{RESULTS}

Phosphatidylcholine metabolism in renal slices. The rate of $\left[{ }^{14} \mathrm{C}\right]$ choline incorporation into renal cortical phospholipid was significantly modified by the addition of any one of eight amino acids to the medium (Fig. 1). Amino acid modulation of the rate of $\left[{ }^{14} \mathrm{C}\right]$ choline incorporation into phospholipid appeared to be concentration-dependent because lysine enhanced the rate by $38 \%(P<0.01)$ at $10 \mathrm{mM}$ and by $152 \%(P<0.001)$ at $20 \mathrm{mM}$, whereas aspartic acid reduced the rate by $33 \%$ $(P<0.01)$ at $1 \mathrm{mM}$ and by $53 \%(P<0.001)$ at $5 \mathrm{mM}$. To evaluate the biochemical locus of amino acid action, slices were incubated at various $\left[{ }^{14} \mathrm{C}\right]$ choline concentrations and the formation of the intermediate compounds in the phosphatidylcholine biosynthetic pathway were measured. The presence of lysine compared to glucose
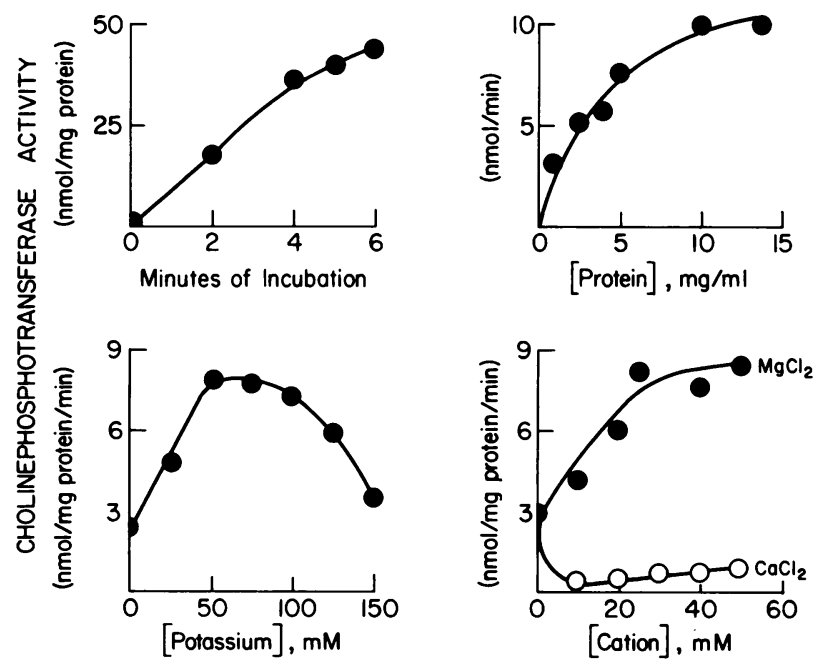

FIGURE 3 Characterization of renal microsomal CDP-choline: 1,2-diacylglycerol cholinephosphotransferase activity. The effect of time, and the concentration of protein, potassium, magnesium, or calcium was assessed as described in Methods. Each value is the mean for at least five determinations on renal cortical tissue pooled from three to six rats.

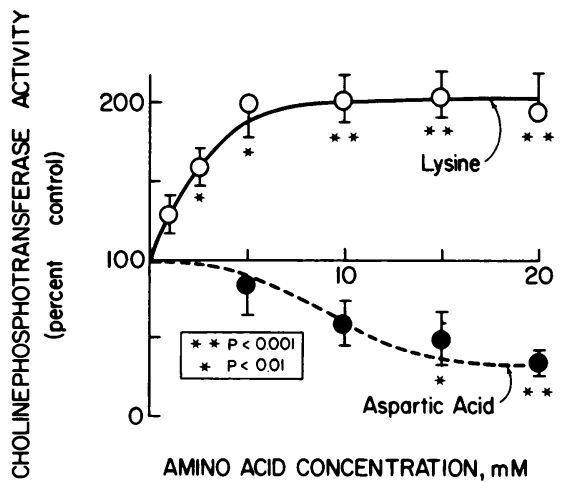

FIGURE 4 Effect of different concentrations of lysine and aspartic acid on microsomal CDP-choline:1,2-diacylglycerol cholinephosphotransferase activity. Enzyme activity was expressed as a percentage of the rate observed at equimolar glucose concentrations. Values are means $\pm S E$ for at least five determinations on renal cortical tissue pooled from six rats.

enhanced the rate of $\left[{ }^{14} \mathrm{C}\right]$ choline incorporation into phospholipid when expressed as a function of the $\left[{ }^{14} \mathrm{C}\right]-$ CDP-choline concentration achieved in the tissue (Fig. 2). In contrast, the rate was decreased by the presence of aspartic acid. The pattern exhibited by lysine as a positive modifier and by aspartic acid as a negative modifier was not observed for $\left[{ }^{14} \mathrm{C}\right]$ choline uptake, $\left[{ }^{14} \mathrm{C}\right]$ phosphorylcholine formation when expressed as a function of the $\left[{ }^{14} \mathrm{C}\right]$ choline concentration in the ICF, or for $\left[{ }^{14} \mathrm{C}\right] \mathrm{CDP}$-choline formation expressed as a function of the ICF $\left[{ }^{14} \mathrm{C}\right]$ phosphorylcholine concentration attained in the slice. These results suggested a direct action of amino acids on the CDP-choline:1,2-diacylglycerol cholinephosphotransferase reaction, in which

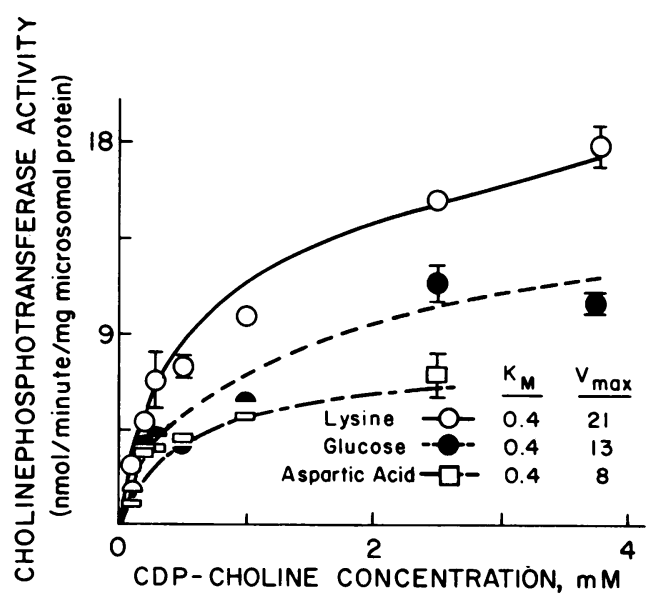

FIGURE 5 The effect of lysine, glucose or aspartic acid on microsomal CDP-choline:1,2-diacylglycerol cholinephosphotransferase activity at various CDP-choline concentrations. Values are means $\pm S E$ for at least three determinations on renal cortical tissue pooled from six rats. Values for apparent $K_{\mathrm{m}}$ and $V_{\text {max }}$ were determined by Eadie-Hofstee analysis. 


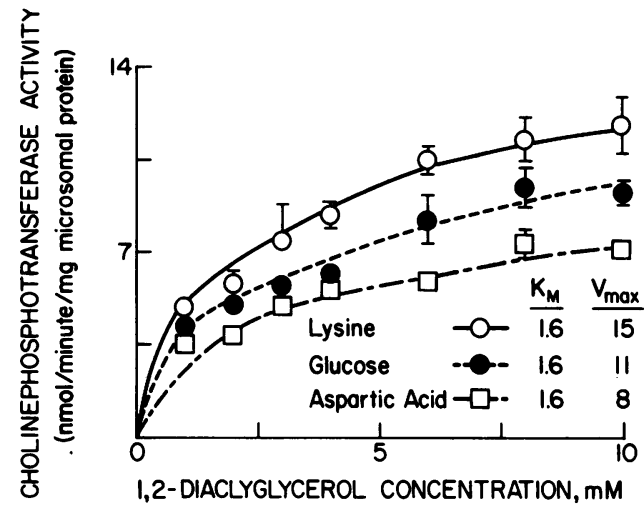

FIGURE 6 The effect of lysine, glucose or aspartic acid on microsomal CDP-choline:1,2-diacylglycerol cholinephosphotransferase activity at various 1,2-diacylglycerol concentrations. Values are means $\pm S E$ for at least three determinations on renal cortical tissue pooled from six rats. Values for apparent $K_{\mathrm{m}}$ and $V_{\max }$ were determined by Eadie-Hofstee analysis.

CDP-choline and 1,2-diacylglycerol are incorporated into phosphatidylcholine.

Cholinephosphotransferase activity in renal microsomes. Enzyme activity was constant for $4 \mathrm{~min}$, and between 1 and $5 \mathrm{mg}$ of microsomal protein per milliliter of reaction mixture (Fig. 3). Maximal rates were obtained by reducing the potassium concentration from 150 to $50 \mathrm{mM}$ and by raising the magnesium concentration to $25 \mathrm{mM}$. The inhibitory effect of calcium was minimized by the addition of EGTA during microsomal isolation. The addition of $2 \%$ sodium deoxycholate to the homogenizing medium inhibited enzyme activity by $95 \%$. Microsomal enzyme activity was about 50 -fold higher than that observed in tissue homogenates.

As in the intact cells lysine increased and aspartic acid decreased enzyme activity in a concentrationdependent manner (Fig. 4). These amino acids modified enzyme activity by altering the $V_{\max }$ but not the apparent $K_{\mathrm{m}}$ for both CDP-choline and 1,2-diacylglycerol (Figs. 5 and 6). The $K_{\mathrm{m}}$ for CDP-choline was $0.4 \mathrm{mM}$ with amino acids or glucose, whereas the $V_{\max }$ in the presence of lysine was 2.6 -fold higher than with aspartic acid (Fig. 5). These amino acids did not change the apparent $K_{\mathrm{m}}$ of $1.6 \mathrm{mM}$ for 1,2-diacylglycerol, however, the addition of lysine resulted in a $V_{\max }$ that was 1.9fold higher than with aspartic acid (Fig. 6). The capacity of these amino acids to modify enzyme activity was not a strict function of their electrical charge since tryptophan, which is uncharged, increased activity by $73 \%$ $(P<0.001)$ compared to glucose.

\section{DISCUSSION}

During renal growth increased phospholipid biosynthesis is required for new membrane and organelle formation. We previously demonstrated that renal cortical cells from normal rats used the Kennedy pathway for the biosynthesis of phosphatidylcholine, the major renal membrane phospholipid (8). Increased rates of biosynthesis via this pathway have been reported during renal regeneration after acute tubular necrosis (1), potassium depletion nephropathy $(8,15,17)$, and compensatory growth after uninephrectomy $(14,25)$. Phosphatidylcholine biosynthesis during renal regeneration after acute tubular necrosis is augmented by the provision of amino acids in vivo and in vitro $(2,3)$. Amino acids appear to act by increasing choline uptake and the rates of the choline kinase and cholinephosphotransferase reactions. Enhanced phosphatidylcholine biosynthesis during potassium depletion nephropathy, which is mediated by increments in choline uptake and in the rate of the cholinephosphotransferase reaction, is also associated with marked alterations in amino acid metabolism. In these growing renal cells the uptake and concentration of lysine and arginine are increased (15, 2628 ), whereas the uptake of aspartic acid and glutamic acid are reduced (15).

In this study amino acids stimulated phosphatidylcholine biosynthesis in vitro in renal tissue from normal rats (Fig. 1). The locus of amino acid action appeared to be at the cholinephosphotransferase reaction in both intact cells (Fig. 2) and in microsomal preparations (Figs. 4-6). The capacity of amino acids to modulate enzyme activity by altering the $V_{\max }$ without changing the apparent $K_{\mathrm{m}}$ suggests that they can modify the number of active enzymatic sites. Amino acids could exert their effect on the enzyme protein or on the phospholipid or glycoprotein environment of this membrane-bound enzyme.

These observations suggest that the relative concentration of amino acids in the cell could determine the rate of phosphatidylcholine biosynthesis, since specific amino acids can modulate cholinephosphotransferase activity. The results also suggest a mechanism that integrates phosphatidylcholine and protein biosynthesis for cell membrane formation. Under metabolic, hormonal, or therapeutic conditions that increase amino acid supply protein synthesis can be augmented (9-13), and if the balance between amino acids favors an increase in cholinephosphotransferase activity, phosphatidylcholine biosynthesis could be increased as well so that new membrane formation could be enhanced.

\section{ACKNOWLEDGMENTS}

We thank Dr. G. S. Getz and Dr. A. M. Scanu for a critical review of this manuscript, and Joel Block for technical assistance.

This work was supported in part by U. S. Public Health Service grants AM 18413 and GM 22328, and by the Chicago Heart Association.

\section{REFERENCES}

1. Toback, F. G., L. J. Havener, R. C. Dodd, and B. H. Spargo. 1977. Phospholipid metabolism during renal regeneration 
after acute tubular necrosis. Am. J. Physiol. 232: E216E222.

2. Toback, F. G. 1977. Amino acid enhancement of renal regeneration after acute tubular necrosis. Kidney Int. 12: 193-198.

3. Toback, F. G., D. E. Teegarden, and L. J. Havener. 1979. Amino acid-mediated stimulation of phospholipid biosynthesis after acute tubular necrosis. Kidney Int. 15: $542-547$.

4. Kennedy, E. P., and S. B. Weiss. 1956. The function of cytidine coenzymes in the biosynthesis of phospholipides. J. Biol. Chem. 222: 193-214.

5. Getz, G. S., W. Bartley, F. Stirpe, B. M. Notton, A. Renshaw, and D. S. Robinson. 1961. The lipid composition of rat-liver-cell sap. Biochem. J. 81: 214-220.

6. Plagemann, P. G. W. 1968. Choline metabolism and membrane formation in rat hepatoma cells grown in suspension culture. I. Incorporation of choline into phosphatidylcholine of mitochondria and other membranous structures and effect of metabolic inhibitors. Arch. Biochem. Biophys. 128: 70-87.

7. Rouser, G., G. Simon, and G. Kritchevsky. 1969. Species variations in phospholipid class distribution of organs. I. Kidney, liver and spleen. Lipids. 4: 599-606.

8. Toback, F. G., L. J. Havener, and B. H. Spargo. 1977. Stimulation of renal phospholipid formation during potassium depletion. Am. J. Physiol. 233: E212-E218.

9. Toback, F. G., R. C. Dodd, E. R. Maier, and L. J. Havener. 1979. Amino acid enhancement of renal protein synthesis during regeneration after acute tubular necrosis. Clin. Res. 27: 432A. (Abstr.)

10. Hanking, B. M., and S. Roberts. 1965. Influence of alterations in intracellular levels of amino-acids on proteinsynthesizing activity of isolated ribosomes. Nature (Lond.). 207: 862-864.

11. Baliga, B. S., A. W. Pronczuk, and H. N. Munro. 1968. Regulation of polysome aggregation in a cell-free system through amino acid supply. J. Mol. Biol. 34: 199-218.

12. Jefferson, L. S., and A. Korner. 1969. Influence of amino acid supply on ribosomes and protein synthesis of perfused rat liver. Biochem. J. 111: 703-712.

13. Morgan, H. E., D. C. N. Earl, A. Broadus, E. B. Wolpert, K. E. Giger, and L. S. Jefferson. 1971. Regulation of protein synthesis in heart muscle. I. Effect of amino acid levels on protein synthesis. J. Biol. Chem. 246: 2152-2162.

14. Toback, F. G., P. D. Smith, and L. M. Lowenstein. 1974. Phospholipid metabolism in the initiation of renal com- pensatory growth after acute reduction of renal mass. $J$. Clin. Invest. 54: 91-97.

15. Toback, F. G., and L. J. Havener. 1979. Mechanism of enhanced phospholipid formation during potassium depletion nephropathy. Am. J. Physiol. 236: E429-E433.

16. Getz, G. S., S. Jakovcic, J. Heywood, J. Frank, and M. Rabinowitz. 1970. A two-dimensional thin-layer chromatographic system for phospholipid separation. The analysis of yeast phospholipids. Biochim. Biophys. Acta. 218: 441-452.

17. Toback, F. G., N. G. Ordóñez, S. L. Bortz, and B. H. Spargo. 1976. Zonal changes in renal structure and phospholipid metabolism in potassium-deficient rats. Lab. Invest. 34: 115-124.

18. Lowenstein, L. M., I. Smith, and S. Segal. 1968. Amino acid transport in the rat renal papilla. Biochim. Biophys. Acta. 150: 73-81.

19. Weiss, S. B., S. W. Smith, and E. P. Kennedy. 1958. The enzymatic formation of lecithin from cytidine diphosphate choline and D-1,2-diglyceride. J. Biol. Chem. 231: 53-64.

20. Kennedy, E. P. 1962. Phosphorylcholine-glyceride transferase. Methods Enzymol. 5: 484-486.

21. Lowry, O. H., N. J. Rosebrough, A. L. Farr, and R. J. Randall. 1951. Protein measurement with the Folin phenol reagent. J. Biol. Chem. 193: 265-275.

22. Snedecor, G. W., and W. G. Cochran. 1967. Statistical Methods. Iowa State University Press, Ames. 32-65, 135- 171 .

23. Eadie, G. S. 1942. The inhibition of cholinesterase by physostigmine and prostigmine. J. Biol. Chem. 146: 85-93.

24. Hofstee, B. H. J. 1956. Graphical analysis of single enzyme systems. Enzymologia. 17: 273-278.

25. Bean, G. H., and L. M. Lowenstein. 1978. Choline pathways during normal and stimulated renal growth in rats. J. Clin. Invest. 61: 1551-1554.

26. Brandt, I. K., V. A. Matalka, and J. T. Combs. 1960. Amino acids in muscle and kidney of potassium-deficient rats. Am. J. Physiol. 199: 39-42.

27. Eckel, R. E., J. E. C. Norris, and C. E. Pope II. 1958. Basic amino acids as intracellular cations in $\mathrm{K}$ deficiency. Am. J. Physiol. 193: 644-652.

28. Iacobellis, M., E. Muntwyler, and C. L. Dodgen. 1956. Free amino acid patterns of certain tissues from potassium and/or protein-deficient rats. Am. J. Physiol. 185: $275-278$. 